\title{
A Triassic spider from Italy
}

Fabio M. Dalla Vecchia and Paul A. Selden

Acta Palaeontologica Polonica 58 (2), 2013: 325-330 doi: http://dx.doi.org/10.4202/app.2011.0132

A new fossil spider from the Triassic (Norian) Dolomia di Forni Formation of Friuli, Italy, is described as Friularachne rigoi gen. et sp. nov. This find brings the number of known Triassic spider species to four. The specimen is an adult male, and consideration of various features, including enlarged, porrect chelicerae, subequal leg length, and presence of a dorsal scutum, point to its identity as a possible member of the mygalomorph superfamily Atypoidea. If correct, this would extend the geological record of the superfamily some 98-115 Ma from the late Early Cretaceous (?Albian, c. 100-112 Ma) to the late middle-early late Norian (c. 210-215 Ma).

FabioM.Dalla Vecchia [fabio.dallavecchia@icp.cat], Institut Català de Paleontologia “M. Crusafont”, C/ Escola Industrial 23, E-08201 Sabadell, Spain; Paul A. Selden [selden@ku.edu], Paleontological Institute and Department of Geology, University of Kansas, Lawrence, Kansas 66045, USA and Natural History Museum, Cromwell Road, London SW7 5BD, UK.

This is an open-access article distributed under the terms of the Creative Commons Attribution License (for details please see creativecommons.org), which permits unrestricted use, distribution, and reproduction in any medium, provided the original author and source are credited. 